\title{
TEACHING WRITING NARRATIVE TEXT BY USING COLLABORATIVE LEARNING
}

\author{
Indra Rizki ${ }^{1}$, Deyan Noufaldi², Yanuarti Apsari ${ }^{3}$ \\ ${ }^{1}$ IKIP Siliwangi \\ ${ }^{2}$ IKIP Siliwangi \\ ${ }^{3}$ IKIP Siliwangi \\ ${ }^{1}$ indrarizki99@gmail.com , 2 deyannoufaldi@gmail.com, ${ }^{3}$ yanuar.apsari1@gmail.com
}

\begin{abstract}
Writing is an important skill that should be mastered by English learner. This research deals with teaching writing narrative text by using Collaborative Learning Approach (round table technique) and Scientific Approach. The subjects of this research were X RPL 1 as experimental class and X RPL 3 as control class. Both classes consist of 33 students. The objectives of this research are to know wheter or not the difference between students' writing ability who were taught by using Collaborative Learning. This research employs the quasi experimental design. The instrument of this ressearch are writing test (pre-test and post test), observation, and interview. The data were analyzed by using statistical product and service solution (SPSS) 25 which through the normality and mann whitney process. The findings showed that the calculation result of gain score showed that the significance value was lower than 0.05 $(0.0049<0.05)$ which means there is a difference between students who were taught by Collaborative Learning and those who were taught by using Scientific Approach.
\end{abstract}

Keywords: Writing, Narrative, Collaborative Learning, Round Table Technique

\section{INTRODUCTION}

In English learning, there are four macro skills that should be learnt by students. The skills are reading, listening, writing and speaking. Writing is the one of four English skills that should be mastered by learner. Harmer (2004, p.31) as cited in Apsari (2018) stated that "writing has always formed part of the syllabus in the teaching English". Writing is a process of arranging words in which people express their thoughts, idea, feeling and opinion. Writing can be used as a communication tools in readable form. Writing can develop the students' critical thinking. "On a general basis, writing can teach critical thinking by helping student's organize, summarize, and integrate and synthesize diverse element into a coherent whole" Barkley et al (2005) as cited in Sipayung (2016).

However, writing in English is often a challenge because it involves many components including grammar accuracy, sentence structure, choice of words and so on. Compared to other three skill, writing is one of the most difficult language skill to achieve by the students and to teach by the teachers Alwasilah (2005) as cited in Apsari (2018). Therefore, it is no wonder if writing in English is sometimes still a difficult thing for both non- native and native speakers. Previous studies revealed that many Indonesian students as an English for Foreign Languange (EFL) learner still have many problems in learning it because writing itself involves aspects of logically ordered and grammatical form. They also never think that english important, many of them also don't put much effort to study it. Many students feel difficult to develop the ideas of what they want and put it down the ideas into sentence and even more complicated in grammar and diction. As Raimes (1983) cited in Saleh \& Ibnian (2017) thinks that "when students 
complain about how difficult it is to write in a second language, they are talking not only about the difficulty of putting the right words and using the correct grammar but also about the difficulty of finding and expressing ideas in a new language".

Owing to the problem, the researcher figured out the solution to improve students' writing ability by using Collaborative Learning and Scientific Approach. Collaborative is a good way to teach writing because it facilitates the students to work in pair or group in creating the text. According to Hadjerrouit (2017) as cited in Aliyev (2017), collaborative writing offers opportunities not only to practice literature review, academic reading and writing, but also to stimulate reflection, knowledge sharing, and critical thinking. Specifically, the researcher used the round table technique in collaborrative learning to teach writing. Barkley et al (2005) as cited in Sipayung (2016) defines that "Round table is a technique in wich students take turns responding to a prompt by writing several words, phrases, or several sentences before passing the paper along to other who do the same". Round Table can help the students to explore their idea in writing and develop their thinking, as Mandal (2009) in Fitri, Azhar \& Eliwarti (2017) states that Round Table Technique is useful for brainstorming because each student in the group take turns in stating their findings, ideas, or opinions and the ideas can be used to develop a piece of good paragraph on a given topic. By applying this method, students work together in group and learn how to develop their ideas, and express it in writing. Therefore, this method is hoped can improve strudents' writing skill.

Furthermore, scientific approach is one of learning model in today's Indonesian curriculum which is called 2013 curriculum. It is a students centered learning. It is kind of learning that make students learn to solve problems through examination or observation. Scientific approach is believed to be able to develop students' affection, skills, and knowledge. As Suharyadi (2013) in Ratnaningsih (2017) states that "scientific approach is paramount to improve the quality of teaching and learning. It directs the students to develop and integrate their attitudes, skills and knowledge".

Based on the description above the researcher interested in conducting the research that entitled "Teaching writing narrative text by using collaborative learning approach and scientific approach".

\section{Definition of Writing}

According to Brown (2001), writing is a process of puting ideas down on paper to transform thought into words, to sharpen main ideas, and to give structure, and coherent organization into its work.

Linse (2006:98) in Masitoh and Suprijadi (2015) also stated that writing is a combination of process to find an ideas and putting them on paper and do some work with it.

\section{Collaborative Approach}

According to Barkley et al. (2005) Collaborative learning refers to learning activities expressly designed for and carried out through pairs or small interactive groups. Furthermore, Laal \& Mohammad (2012) states that Collaborative learning is an educational approach to teaching that involves groups of learners working together to solve a problem.

Based on some expert opinions above the researcher concludes that Collaborative Learning is a learning model that helps students to understand learning material by forming students in one group to work together to solve problems in achieving learning goals with varied skills and students are able to actualize their thoughts.

\section{Round Table}


According to Barkley et al. (2005) Round table is a technique in wich students take turns responding to a prompt by writing one or two words, or sentences before passing the paper along to other who do the same. Moreover, Kagan (2009) cited in Muazizah \& Riwayatiningsih (2016) states "students take turn generating written responses, solving problems, or making a contribution to a project. In round table, students take turn in their teams". It means, this technique make each students participate actively in learning and they can deliver their thought or idea easily in small group.

\section{Scientific Approach}

According to Ahmad (2014) in (Pratiwi, Harahap, Sofyan, Education, \& Program, n.d.), availability of 2013 curriculum expectedly could develop and could improve the chances for the learners to take part directly in the learning process. This curriculum has four aspects namely character building, literacy, 4C (communication, collaboration, critical thinking and problem-based, creativity and innovation), and HOTS (higher-order thinking skill).

\section{METHOD}

In carrying out the research, researcher used Quantitative method. According to Crowl (1996) cited in Masitoh \& Suprijadi (2015) "Quantitative research methods are used to examine questions that can best be answered by collecting and statistically analyzing data that are in numerical form". In addition, Creswell (2003) in Williams (2007) states, quantitative research "employ strategies of inquiry such as experimental and surveys, and collect data on predetermined instruments that yield statistical data".

The sample of this research was the first grade students of SMK Bina Putra Cihampelas. To obtain the data, the researchers used pre-test and post-test. Pre-test is a test that is given to students before the treatment. The purpose of pre-test is to knoe how far is students' ability in English vocabulary. While, post test is a test that is given after the treatment. Then, the scores were calculated through SPSS to know whether the technique was effective to improve students' vocabulary mastery.

\section{RESULTS AND DISCUSSION}

\section{Results}

The researcher has found the result of this research. The method of this research was quasi experimental group where the researcher used two group pretest and posttest to get the data. The findings of this research included the result of pretest and posttest that the researcher was given to the students of SMP Plus Darussurur.The result of the test can be seen as follow:

Table. 1 Descriptive statistic

\begin{tabular}{|c|c|c|c|c|c|c|}
\hline Variable & \multicolumn{3}{|c|}{ Experimental Class } & \multicolumn{3}{|c|}{ Control Class } \\
\hline $\begin{array}{c}\text { Writing } \\
\text { Skill }\end{array}$ & $\begin{array}{c}\text { Pre } \\
\text { Test }\end{array}$ & $\begin{array}{l}\text { Post } \\
\text { Test }\end{array}$ & $\begin{array}{c}\mathrm{N}- \\
\text { gain }\end{array}$ & $\begin{array}{l}\text { Pre } \\
\text { Test }\end{array}$ & $\begin{array}{l}\text { Post } \\
\text { Test }\end{array}$ & $\begin{array}{c}\mathrm{N}- \\
\text { gain }\end{array}$ \\
\hline $\mathrm{N}$ & 34 & 67 & 0,5 & 34 & 53,5 & 0,30 \\
\hline Mean & 50,38 & 78,30 & 0,55 & 56,61 & 73,11 & 0,36 \\
\hline
\end{tabular}




\begin{tabular}{lcccccc}
\hline Min & 34 & 59,5 & 0,18 & 34 & 53 & $-0,42$ \\
& & & & & & \\
\hline Max & 74,5 & 94,5 & 0,88 & 76 & 90 & 0,71 \\
& & & & & & \\
\hline Std. Deviation & 13,40 & 8,68 & 0,18 & 13,45 & 12,37 & 0,29
\end{tabular}

The table 1 shows that the mean pretest score of experimental class is 50,38 with minimum score 34 and maximum score 74,5. Then mean pre test of control class is 56,61 with minimum score 34 and maximum score 76 . Then from the table above we can see the mean of post test in experimental class is 78,30 with minimum score 59,5 and maximum score 94,5. Then mean score of post test in control class is 73,11 with minimun score 53 and maximum score 90 . From the data above, it can be seen that the mean score of experimental class and control class is different. However, the data should be tested by the normality test and homogeneity test.

\section{a. Pretest Analysis}

1) Normality Test

The normality test of pre test in Experimental class (using collaborative) and Control Class (using scientific approach).

Criteria of Normality test : if sig $>0.05$ then the data is normally distributed.

Table .2 The pre-test normality of experimental and control class

\section{Tests of Normality}

\begin{tabular}{lllllllll}
\hline & & \multicolumn{3}{c}{ Kolmogorov-Smirnov $^{\text {p }}$} & \multicolumn{4}{c}{ Shapiro-Wilk } \\
\cline { 2 - 8 } & $\begin{array}{l}\text { pendekatan } \\
\text { pembelajaran }\end{array}$ & Statistic & Df & Sig. & Statistic & df & Sig. \\
\hline pre test & Collaborative learning &, 208 & 33 &, 001 &, 867 & 33 &, 001 \\
\cline { 2 - 8 } & Scientific Approach &, 223 & 33 &, 000 &, 865 & 33 &, 001 \\
\hline
\end{tabular}

a. Lilliefors Significance Correction

The number of students is 33, then the data taken is Kolmogorov-smirnov. From the table above, it found that Sig pre-test (using Collaborative) : $0,001<0,05$ then the data is not normally distributed. And Sig pre-test (Using Scientific) : $0,000<0,05$ then the data is not normally distributed. Because both data are not normally distributed, then proceed to the Mann whitney test.

2) Mann-Whitney test

Hypothesis (2 tiled)

$\mathrm{H}_{0:}$ : There is no different between students' writing ability in experimental class and control class.

$\mathrm{H}_{0}: \mu 1=\mu 2$
$\mathrm{H}_{1}: \mu 1 \neq \mu 2$ 
a) If the asymp sig is greater (>) than 0.05 then $\mathrm{H} 0$ is accepted. The conclusion is "There is no different between students' writing ability in experimental class and control class."

b) If the asymp sig is smaller $(<)$ than 0.05 then $\mathrm{H} 0$ is rejected. The conclusion is "There is a difference between students' writing ability in experimental class and control class."

The data was presented on the following table:

Table .3 Mann-Whitney of pretest

Test Statistics ${ }^{a}$

\begin{tabular}{lr} 
& \multicolumn{1}{c}{ pre test } \\
\hline Mann-Whitney U & 389,500 \\
\hline Wilcoxon W & 950,500 \\
\hline$Z$ & $-1,994$ \\
\hline Asymp. Sig. (2-tailed) &, 046 \\
\hline
\end{tabular}

a. Grouping Variable: pendekatan

pembelajaran

The table above shows that the result of Mann Withney Test is 0.046 .

Asymp. sig. $0.046<0.05$ then $\mathrm{H}_{0}$ is rejected. There is a difference between students' writing ability in experimental class and control class." Because there is a difference, then the next step is processing N-Gain.

a. N-Gain Analysis

This part will show the data of normality test, and Mann Whitney test.

1) Normality Test of N-Gain

In this part, researcher will show the normality test of pre test in Experimental class (using Collaborative) and Control Class (Using Scientific Approach).

Criteria of Normality test : if sig $>0.05$ then the data is normally distributed.

Table 4

Normality Test of N-Gain

\section{Tests of Normality}

\begin{tabular}{|c|c|c|c|c|c|}
\hline pendekatan & $\begin{array}{l}\text { Kolmogorov } \\
\text { Smirnov }^{\mathrm{a}}\end{array}$ & & Shap & $-\mathrm{Wi}$ & \\
\hline pembelajaran & Statistic Df & Sig. & Stati & Df & Sig. \\
\hline Gain Collaborative learning &, 115 & ,200* & ,972 & 33 &, 542 \\
\hline Scientific Approach & 169 & 017 & ,907 & 33 & ,008 \\
\hline
\end{tabular}

The number of students is 33, then the data taken is Kolmogorov-smirnov.

From the table above it can be seen that:

Sig pre-test (using Collaborative) : 0,200 >0,05 then the data is normally distributed. And sig pre-test (Using Scientific Approach) : 0,017 <0,05 then the data is not normally distributed.

Because one of those data is not normally distributed, then proceed to the Mann whitney test. 
2) Mann Whitney Test of N-Gain

Criteria of Mann Whitney Test:

Hypothesis

$\mathrm{H}_{0:}$ : There is no different between teaching students' writing narrative text using collaborative learning and scientific approach.

$\mathrm{H}_{0}: \mu 1=\mu 2$

$\mathrm{H}_{1}: \mu 1 \neq \mu 2$

a) If the asymp sig is greater (>) than 0.05 then $\mathrm{HO}$ is accepted. The conclusion is "There is no different between teaching students' writing narrative text using collaborative learning and scientific approach."

b) If the asymp sig is smaller $(<)$ than 0.05 then $\mathrm{H} 0$ is rejected. The conclusion is "There is a difference between teaching students' writing narrative text using collaborative learning and scientific approach."

Table 5

Mann Whitney Test of N-Gain

Test Statistics $^{\text {a }}$

\begin{tabular}{ll}
\hline & Gain \\
\hline Mann-Whitney U & 341,500 \\
\hline Wilcoxon W & 902,500 \\
\hline$Z$ & $-2,604$ \\
\hline $\begin{array}{l}\text { Asymp. Sig. } \\
\text { tailed) }\end{array}$ & $(2-, 009$ \\
\hline
\end{tabular}

The table above shows that the result of Mann Withney Test is 0.009 (2-tiled) it means the result is 0.0045 for 1-tiled.

Asymp. sig. $0.0045<0.05$ then $\mathrm{H}_{0}$ is rejected. It means that there is a difference between students who were taught by using Collaborative Learning and Scientific Approach.

\section{Discussion}

As it has been mentioned in chapter one that conduct in order to know wheter or not there is any difference between the use of Collaborative Learning and Scientific Approach in teaching writing narrative text, the implementation of Collaborative Learning and Scientific Approach to related skill, and also about students' difficulties in writing through Collaborative Learning and Scientific Approach. To answer those questions above, the researcher used the processing test result for the first question, the observation for the second question, and the interview for the third question.

Based on the data, researcher got the result of pre-test and post-test between the experimental group (Round table technique) and control group (Scientific Approach) were different. Looking from the mean score of both groups, the experimental pre-test score is 50.38 and post-test score is 78.30. The statistical data showed that there is 0.55 point of gain in the mean score of the test in experimental group. Meanwhile, the mean of control pre-test score is 56.61 and post-test is 73.11. The statistical data showed that there is 0.36 point of gain in the mean score of the test in control group. From the data, it can be seen that the experimental group had a higher gain score after taught by Collaborative Learning.

To know if the hypothesis is accepted or rejected, the researcher processed the data of pre-test, post-test or N-gain by using IBM SPSS ver. 25 . The test consist of a normality test, and the 
significance test. These tests are using the level of significance at 5\% $(\alpha=0.05)$ to determine whether the $\mathrm{H}_{0}$ is accepted or rejected. On the normality test, pretest score of experimental group (0.001) is not normally distributed, while the control group (0.000) is also not normally distributed. Because both of data are not normally distributed then the process continue to the Mann Whitney $U$ test. The result of pretest score (0.046) is less than 0.05 , which means that $\mathrm{H}_{0}$ is rejected or there is a difference betwee students' writing ability in experimentl class and control class, then the analysis was continued on the $\mathrm{N}$-gain analysis. On the normality test, $\mathrm{N}$ gain scores of experimental group (0.200) is normally distributed and control group (0.017) is not normally distributed. The analysis was continued to Mann Whitney $U$ test. The result of the test is 0.009 , which means that $\mathrm{H}_{0}$ is rejected or there is a difference between students who were taught by Collaborrative Learning and those who were taught by Scientific Approach.

\section{CONCLUSION}

Based on the research finding, the statistical result showed that in the Mann Whitney test of $\mathrm{N}$ gain got asymp sig. 1 tiled 0.0045 . it smaller than 0.05 which means the null hypothesis $\left(\mathrm{H}_{0}\right)$ is rejected. It means that the answer of research problem was proven that there is a difference between students' writing skill in narrative text by using collaborative learning and scientific approach.

\section{ACKNOWLEDGMENTS}

The researcher thank our colleagues from IKIP Siliwangi Bandung who provided insight and expertise that greatly assisted the research, although they may not agree with all of the interpretations/conclusions of this paper.The researcher are thankful to the Lecture, Mrs.Yanuarti Apsari, M.Pd for guiding us until finished the project, and provided expertise that greatly assisted the research. Although they may not agree with all of the interpretations provided in this paper. We are also grateful to family and friends for praying and motivate the writer to finish the study at IKIP Siliwangi Bandung. The writer hope this article could be helpful to reader or other researcher in the future.

\section{REFERENCES}

Aliyev, A. (2017). Improving English Writing Skills Of Non-Native Undergraduate Learners With The Help Of Movies Supported By Online Technologies. Journal Of Education In Black Sea Region, 2(2), 2-16. Https://Doi.Org/10.31578/Jebs.V2i2.38

Alwasilah, A. C. (2005). Pokoknya Menulis: Cara Baru. Bandung: PT Kiblat Buku Utama.

Apsari, Y. (2018). Reflective Reading Journal In Teaching Writing. Indonesian EFL Journal, 4(2), 39. Https://Doi.Org/10.25134/Ieflj.V4i2.1374

Barkley, E. F., Cross, K. P., \& Major, C. H. (2005). Collaborative Learning Tecniques (1st Ed.). San Francisco: Jossey Bass.

Brown, H. D. (2001). Teaching By Principles: An Interactive Approach To Teaching Pedagogy ((2nd Ed.)). New York: Pearson Education, Inc.

Fitri . Azhar \& Eliwarti. (2017). The Effect Of Round Table Technique On The Writing Ability In Recount Text Of The Second Year Students Of Smpn 1 Kubu Pengaruh Teknik Meja Bundar Pada Kemampuan Menulis Recount Text Siswa Kelas 8 Smpn 1 Kubu. 1-10.

Hadjerrouit, S. (2017). A Collaborative Writing Approach To Wikis: Design, Implementation, And Evaluation. Issues In Informing Science And Information Technology, 8, 431-449. Https://Doi.Org/10.28945/1432

Laal, M., \& Mohammad, S. (2012). Social And. O0(2011), 486-490. 
Https://Doi.Org/10.1016/J.Sbspro.2011.12.091

Masitoh, S., \& Suprijadi, D. (2015). Improving Students' Ability In Writing Descriptive Text Using Genre Based Approach (Gba) At The Eighth Grade Students Of Smp Islam Terpadu Fitrah Insani. 3(April), 38-52.

Muazizah, H. L., \& Riwayatiningsih, R. (2016). The Effect Of Roundtable Technique To The Students' Reading Comprehension Achievement In Narrative Text To The Second Year Students MA HM Tribakti Kediri. 1(February).

Pratiwi, F. D., Harahap, A., Sofyan, D., Education, E., \& Program, P. (N.D.). The Implementing Of Scientific Approach In Teaching English At Smpn Rejang Lebong.

Ratnaningsih, S. (2017). Scientific Approach Of 2013 Curriculum: Teachers Implementation In English Language Teaching. English Review: Journal Of English Education, 6(1), 33. Https://Doi.Org/10.25134/Erjee.V6i1.792

Saleh, S., \& Ibnian, K. (2017). Writing Difficulties Encountered By Jordanian EFL Learners. Asian Journal Of Humanities And Social Studies, 05(03), 2321-2799. Retrieved From Www.Ajouronline.Com

Sipayung, K. T. (2016). The Implementation Of Collaborative Writing Method To Improve Students' Writing Of Descriptive Genre At SMP Negeri 3 Percut Sei Tuan On Grade VIII At The Academic Year. 88-99.

Williams, C. (2007). Research Methods. 5(3), 65-72. 